\title{
Reforming accountability in international NGOs: Making sense of conflicting feedback
}

\footnotetext{
Published as: Davis, Thomas WD, Kate Macdonald, and Scott Brenton. "Reforming accountability in international NGOs: making sense of conflicting feedback." Development in Practice 22.7

(2012): 946-961.
}

\author{
Thomas W D Davis, Kate Macdonald \& Scott Brenton \\ School of Social \& Political Sciences, University of Melbourne
}

tdavis@unimelb.edu.au

sbrenton@unimelb.edu.au

kmac@unimelb.edu.au 


\begin{abstract}
Home and field office staff disagreement often impedes international development NGOs (INGOs) from making their accountability systems more responsive to partner and community concerns. Drawing on a staff survey, and qualitative interviews across four country programs, of a major INGO, three interlocking explanations for this disagreement are suggested: that staff perceive accountability practices differently because they place greater interpretive weight on practices most relevant to their own organisational roles; that divergent views reflect substantively different normative beliefs about accountability; and that differing assessments of accountability practices reflect a strategic misrepresentation of field country experiences as a rational response to power differentials.
\end{abstract}

Key Words: accountability, nongovernmental organisations, new institutionalism, organisational change, field offices, power 


\section{Reforming accountability in international NGOs: \\ Making sense of conflicting feedback}

\section{Introduction}

The virtues of international donor agencies and international non-governmental development organisations (INGOs) extending voice and control to field country offices and partners with whom they work have been widely promoted (Walker 2009). This mirrors the increasing value placed on responsiveness to stakeholders in wider social governance literatures (Reddell 2004). From this perspective, accountability arrangements that demand responsiveness by home office decision makers to field office staff, partners and communities are regarded as having intrinsic democratic value, insofar as they can empower field country constituencies to play more meaningful roles in the decision making processes that affect them (Roche 2010). They are also considered to have instrumental value by facilitating input from a diversity of stakeholders to enrich organisational decision making, build capacity among local organisations and facilitate participation in wider processes of social and political change (Brown and Moore 2001; Newell 2006).

Many international development NGOs have responded to this call for strengthened accountability to field country constituencies by investing significant resources in evaluating and reforming their transnational accountability arrangements. Such processes of evaluation and reform depend importantly on the implementation of effective processes of organisational change. While the conditions for effective organisational change are debated within a huge literature in both management and policy studies, most organisational change theorists concur at least on the importance of establishing an agreed understanding of what change is required as a foundation for driving change processes (Duncan and Dutton, 1987; Gioia and Chittipeddi 1991).

Building such agreement depends importantly on the capacity to make sense of feedback received from staff and stakeholders across the organisation, therefore enabling this to inform a shared agenda for reform. However, this task is complicated when NGOs receive 'mixed messages' from different groups of staff and stakeholders. This challenge is particularly likely for many international development NGOs because of the diverse organisational and social environments that 
their activities traverse. Although INGOs structure relationships between home offices and field country actors in a variety of ways, such arrangements are typically mediated by a range of organisational levels, involving some mix of home country offices, field country offices, local partner organisations and communities themselves (Anheier and Themudo 2002). The local social and political contexts in which programs and projects are being implemented also vary widely, generating a diversity of experiences and priorities across differently located staff.

These varying experiences can underpin very different views of the relative value, costs or risks of alternative accountability arrangements, as well as of how different efforts designed to strengthen accountability should be prioritised and sequenced. Different actors may also hold contrasting views of the adequacy of existing accountability arrangements, and contrasting diagnoses of where change is needed (as seen in studies on stakeholder dialogue relating to program evaluation and accountability, such as Campbell and Mark (2006)). Such widely varying experiences can make it difficult for differently positioned staff to agree on what kinds of change to accountability practices should be promoted, thereby potentially impeding efforts to reform accountability practices and make them more responsive to field country stakeholders.

In such cases, it is important to try and understand why perceptions vary systematically across different levels of the organisation. Understanding the main reasons for such disagreement is not only of theoretical interest. It also has important implications for the strategies through which INGOs design efforts to strengthen and reform their accountability arrangements. The central goal of this paper is therefore to deepen our understanding of the reasons for disagreement among home and field office staff within INGOs. We conclude with some reflections on the practical implications of our findings.

The paper documents the divergent views of home versus field office staff with reference to results from a detailed empirical study of accountability arrangements within one internationally active development NGO: Oxfam Australia (OAus). We show how perceptions of accountability vary between staff in home and field offices, drawing on both quantitative data from a survey of home and field staff, and qualitative analysis from interviews and focus groups held with field staff, partner NGOs, and communities in four countries (Cambodia, Solomon Islands, Sri Lanka, and Zimbabwe). Material from OAus documents and a series of Australian Council for International Development (ACFID) workshops held in July 2010 with a range of Australian NGOs (including OAus) is also used. A central and rather striking finding of this study is that field staff display 
consistently more favourable perceptions of the organisation's existing accountability practices than do home office staff.

To explain the observed divergence between home and field office staff assessments of existing accountability practices, we draw on broad insights from 'new institutional' theory (Powell and DiMaggio 1991; Hall and Taylor 1996). This theoretical tradition is useful for our purposes because it addresses institutional dynamics within and beyond the organisational boundaries of the INGO, taking account of both organisational arrangements, and the wider social and normative environments in which these are embedded (Scott and Meyer 1991). We draw on insights from this tradition to elaborate three possible explanations for disagreement among staff assessments of existing accountability arrangements and priorities for reform. The three explanations are broadly informed by a new institutional lens in their emphasis on the importance (in differing combinations) of cognitive frames, norms and 'rationally' assessed strategic interests as drivers of divergent accountability assessments.

The first explanation attributes differing assessments to the influence of 'cognitive frames' - or interpretive lenses through which actors make sense of the world - on structuring individual judgements. These cognitive frames are in turn viewed as being conditioned by the distinctive (internal) organisational roles and (external) social and political environments experienced by home versus field office staff. This explanation contends in short that differently positioned actors pay attention to different dimensions of accountability in forming an overall evaluation of accountability practices, with each placing greater implicit weighting on those practices that are most salient to their own roles and experiences.

The second explanation posits that varying organisational and social contexts experienced by home versus field staff lead the two groups to internalise substantively different norms and preferences. On this view, assessments of existing accountability practices vary between home and field office staff because these practices are being implicitly compared against contrasting visions of what desirable or feasible accountability arrangements look like. Field and home office staff, according to this interpretation, often have substantively different interpretations of the costs, benefits and risks of accountability reform.

The third explanation attributes the divergence in documented assessments of accountability practices to a desire on the part of field staff to shape their feedback based on their interpretation of what they think head office wants to hear. This can be viewed as a 'rational' response to the 
unequal power relationship between home and field office, particularly under conditions of resource dependence.

We survey the evidence in favour of each of these three explanations, and suggest that a full understanding of the conflicting feedback offered by field and home staff requires consideration of all three. The first two explanations seem particularly important in explaining the disparity between assessments of 'downwards' accountability (to INGO partners and beneficiaries), while the third explanation helps us understand why the more positive assessments of field staff also extended to 'upwards' forms of accountability (to the INGO home office, Board and donors). We conclude by exploring practical implications for INGOs seeking to promote processes of organisational change to strengthen accountability systems, and make them more responsive to field offices, partners and communities that they work with.

\section{Contrasting evaluations of existing accountability arrangements}

In order to investigate how assessments of NGO accountability vary between differently positioned groups, two categories of staff working for OAus were surveyed: 76 Australian staff working in the head office and 86 locally engaged field staff working in four different countries, predominantly in the Asia-Pacific region. It is worth noting that, in addition to the head-field office division, there were some differences between the two groups regarding the balance of staff roles. While the surveyed staff in home and field locations held a similar array of organisational positionstraversing programs, policy/advocacy, management, finance, and, to a lesser degree, marketing roles-a greater proportion of staff in field offices occupied program-oriented roles focused on the implementation of activities. This was regarded by the researchers as a natural corollary of OAus' head-field office organisational structure. The potential impact of this role differentiation on survey and qualitative research outcomes is discussed later in the article.

Survey questions sought to capture normative visions of accountability (ideas about what accountability arrangements should—and feasibly could-look like), and perceptions and evaluations of existing accountability practices. Participants were first asked to indicate to what degree they believe Oxfam Australia should be and is in practice held accountable for its overall performance to a range of groups including various parts of Oxfam Australia, Oxfam International, governments, communities, supporters and international NGOs. To employ commonly used terms in this area, the survey sought to capture staff perceptions of their 'upward accountability' (to authorities above them in the organisational and governance hierarchy) and 'downward 
accountability' (to partners and 'recipients' of Oxfam support). Participants were also asked to what degree they are personally held accountable for their own performance. They were presented with five options on a Likert scale, with 1 indicating 'Not at all accountable', 2 'Slightly accountable', 3 'Partly accountable', 4 'Significantly accountable', and 5 'Significantly Accountable'. Therefore a higher mean indicates a perception of a higher degree of accountability. The statistically significant results are presented in Table 1.

Table 1: Identification of existing stakeholders

\begin{tabular}{|c|c|c|c|c|}
\hline Stakeholders & & SHOULD & IS & PERSONALLY \\
\hline \multirow{2}{*}{ Oxfam Australia Board } & Aust. & 4.70 & 4.26 & ns \\
\hline & Field & 4.20 & 3.93 & $n s$ \\
\hline \multirow{2}{*}{$\begin{array}{l}\text { Oxfam International \& } \\
\text { Affiliates }\end{array}$} & Aust. & $n s$ & 3.57 & 2.42 \\
\hline & Field & $n s$ & 3.90 & 3.33 \\
\hline \multirow{2}{*}{$\begin{array}{l}\text { Australian government, } \\
\text { e.g. AusAID }\end{array}$} & Aust. & $n s$ & $n s$ & 2.51 \\
\hline & Field & $n s$ & ns & 3.04 \\
\hline \multirow{2}{*}{$\begin{array}{l}\text { Oxfam Australia field } \\
\text { Offices }\end{array}$} & Aust. & ns & 3.23 & 2.42 \\
\hline & Field & $n s$ & 3.93 & 4.27 \\
\hline \multirow{2}{*}{$\begin{array}{l}\text { Governments of field office } \\
\text { countries }\end{array}$} & Aust. & $n s$ & 2.77 & 1.56 \\
\hline & Field & $n s$ & 3.35 & 3.40 \\
\hline \multirow{2}{*}{$\begin{array}{l}\text { Oxfam Australia partner } \\
\text { Organisations }\end{array}$} & Aust. & $n s$ & 2.97 & 2.08 \\
\hline & Field & $n s$ & 3.54 & 3.69 \\
\hline \multirow{2}{*}{$\begin{array}{l}\text { Communities Oxfam } \\
\text { Australia works with }\end{array}$} & Aust. & $n s$ & 3.13 & 2.17 \\
\hline & Field & $n s$ & 3.66 & 3.78 \\
\hline \multirow{2}{*}{$\begin{array}{l}\text { Australian community } \\
\text { supporters of Oxfam } \\
\text { Australia }\end{array}$} & Aust. & $n s$ & 3.26 & 2.46 \\
\hline & Field & $n s$ & 3.85 & 3.40 \\
\hline \multirow{2}{*}{$\begin{array}{l}\text { Other international } \\
\text { NGOs }\end{array}$} & Aust. & 2.80 & 2.36 & 1.81 \\
\hline & Field & 3.30 & 2.88 & 2.94 \\
\hline
\end{tabular}

Significant at a 95\% confidence interval ( $n s=$ not significant)

Survey results reflected strong alignment between the normative visions of accountability arrangements held by home and field office staff, as captured in the question 'to what degree SHOULD Oxfam Australia be held accountable for its overall performance to each stakeholder?'. On this issue, there was no statistically significant difference between ratings by field and home office staff on the importance of Oxfam being held accountable for its performance to 7 of the 9 
nominated stakeholder groups. The only differences were minor: Australian-based staff thought that Oxfam Australia should be more strongly accountable to its Board than did field staff, although the means of both groups were high. Conversely, field staff believed that Oxfam Australia should be held to a higher degree of accountability to other international NGOs than did home office staff; the means of both groups were lower in this case.

Despite such strong alignment between the normative visions of home and field office staff, perceptions of the two groups regarding the performance of existing accountability arrangements within Oxfam differed strikingly. Of particular note, field office staff were consistently less critical in their evaluations of existing accountability arrangements than were home office staff. Field staff perceived Oxfam Australia to be more accountable than did home office staff in relation to almost all categories of stakeholder: Oxfam International \& affiliates, Oxfam Australia field offices, governments of field office countries, Oxfam Australia partner organisations, communities with which Oxfam Australia works, Australian community supporters of Oxfam Australia, and other international NGOs. This tendency of field office staff to assess accountability arrangements in a more favourable light than home office staff was particularly pronounced in assessments of 'downward' as opposed to 'upward' accountability.

The gap between field and home office evaluations of what accountability practices should look like and what they are perceived to actually look like opened up further still when survey respondents were asked to assess the extent to which they felt personally accountable to different categories of Oxfam stakeholders. In each of the cases where there were statistically significant differences between responses of Australian-based and field office staff, it was field staff who felt a higher degree of personal accountability for their own performance. However, the degrees of accountability perceived by both home and field office staff generally remained at the lower and middle ranges of the scale.

A five-point Likert scale was also used to assess experiences and perceptions of Oxfam Australia’s existing performance in relation to a number of more specific dimensions of accountability: transparency, two-way communication, facilitation of formal and informal complaints mechanisms, and responsiveness of the organisation to complaints and proposals from partners and communities. Versions of these elements have been widely recognised in scholarly and practitioner discussions as critical components of INGO accountability (Roche 2010). While perceptions of field office staff were more favourable than those of home office staff in relation to each of these dimensions, for the purposes of this paper we focus on two that revealed the most significant differences and have 
particular implications for the conceptualisation of accountability and its implementation in an organisational context: participation and responsiveness.

Significant differences between home and field office perceptions of OAus' existing performance in relation to stakeholder participation in decision making are presented in Table 2, with higher means indicating higher levels of agreement. Field staff felt that partners (NGOs and communities) had more of a genuine involvement in both upwards and downwards dimensions of accountability: OAus' project planning in the field; country program planning; international advocacy campaigns; the setting of organisational goals, strategies, mission and values; and monitoring and evaluation processes at field, country program and whole-of-organisation level. On average, Australia-based staff disagreed with each of those statements. Field staff also held a stronger perception that OAus asks for feedback on its performance from those communities it is attempting to help.

Table 2: Participation in Oxfam decision making

\begin{tabular}{|c|c|c|}
\hline Statement & & $\begin{array}{l}\text { Level of } \\
\text { Agreement }\end{array}$ \\
\hline \multirow{2}{*}{$\begin{array}{l}\text { I feel I have genuine involvement in Oxfam Australia's project } \\
\text { planning in the field. }\end{array}$} & Aust. & 2.26 \\
\hline & Field & 3.81 \\
\hline \multirow{2}{*}{$\begin{array}{l}\text { I feel I have genuine involvement in Oxfam Australia's country (field } \\
\text { offices and indigenous Australia program sites) program planning. }\end{array}$} & Aust. & 2.25 \\
\hline & Field & 3.71 \\
\hline \multirow{2}{*}{$\begin{array}{l}\text { I feel I have genuine involvement in Oxfam Australia's international } \\
\text { advocacy campaigns. }\end{array}$} & Aust. & 2.14 \\
\hline & Field & 2.78 \\
\hline \multirow{2}{*}{$\begin{array}{l}\text { I feel I have genuine involvement in Oxfam Australia's setting of } \\
\text { organisational goals and strategies. }\end{array}$} & Aust. & 2.68 \\
\hline & Field & 3.23 \\
\hline \multirow{2}{*}{$\begin{array}{l}\text { I feel I have genuine involvement in Oxfam Australia's setting of } \\
\text { organisational mission and values. }\end{array}$} & Aust. & 2.44 \\
\hline & Field & 3.28 \\
\hline \multirow{2}{*}{$\begin{array}{l}\text { I feel I have genuine involvement in Oxfam Australia's monitoring and } \\
\text { evaluation processes at a project level in the field. }\end{array}$} & Aust. & 2.47 \\
\hline & Field & 3.94 \\
\hline \multirow{2}{*}{$\begin{array}{l}\text { I feel I have genuine involvement in Oxfam Australia's monitoring and } \\
\text { evaluation processes at a country (field offices and indigenous Australia } \\
\text { program sites) program level. }\end{array}$} & Aust. & 2.32 \\
\hline & Field & 3.59 \\
\hline \multirow{2}{*}{$\begin{array}{l}\text { I feel I have genuine involvement in Oxfam Australia's monitoring and } \\
\text { evaluation processes at an organisational level. }\end{array}$} & Aust. & 2.90 \\
\hline & Field & 3.53 \\
\hline I feel Oxfam Australia does ask for feedback on its performance from & Aust. & 3.36 \\
\hline
\end{tabular}




\begin{tabular}{|l|l|c|}
\hline Statement & & $\begin{array}{c}\text { Level of } \\
\text { Agreement }\end{array}$ \\
\hline those communities it is attempting to help. & Field & 3.91 \\
\hline Significant at a 95\% confidence interval &
\end{tabular}

Field staff also expressed more favourable evaluations of OAus' performance in relation to responsiveness to proposals and responsiveness to criticisms from communities it is attempting to help, as shown in Table 3. There were statistically significant differences in perception of OAus responsiveness to input from partners and the degree to which OAus explained its responses. There was also a comparatively positive perception on the part of field staff that: OAus alters its mission, values, goals and strategies in response to partner feedback; proposals from partner organisations are taken seriously by Oxfam field offices; and proposals from Oxfam Australia field offices are taken seriously by Oxfam head office.

Table 3: Responsiveness

\begin{tabular}{|c|c|c|}
\hline Statement & & $\begin{array}{c}\text { Level of } \\
\text { Agreement }\end{array}$ \\
\hline \multirow{2}{*}{$\begin{array}{l}\text { Proposals from Oxfam Australia partner organisations are taken seriously } \\
\text { by the Oxfam field offices. }\end{array}$} & Aust. & 3.73 \\
\hline & Field & 4.12 \\
\hline \multirow{2}{*}{$\begin{array}{l}\text { Proposals from Oxfam Australia field offices are taken seriously by } \\
\text { Oxfam head office. }\end{array}$} & Aust. & 3.75 \\
\hline & Field & 4.18 \\
\hline \multirow{2}{*}{$\begin{array}{l}\text { Proposals received by Oxfam Australia head office result in substantive } \\
\text { changes to OAus mission and values. }\end{array}$} & Aust. & 2.61 \\
\hline & Field & 3.54 \\
\hline \multirow{2}{*}{$\begin{array}{l}\text { Proposals received by Oxfam Australia head office result in substantive } \\
\text { changes to OAus goals and strategies. }\end{array}$} & Aust. & 2.68 \\
\hline & Field & 3.52 \\
\hline \multirow{2}{*}{$\begin{array}{l}\text { Proposals received by Oxfam Australia head office result in substantive } \\
\text { changes to country goals and strategies. }\end{array}$} & Aust. & 3.30 \\
\hline & Field & 3.56 \\
\hline \multirow{2}{*}{$\begin{array}{l}\text { Criticisms received by Oxfam Australia head office result in substantive } \\
\text { changes to OAus mission and values. }\end{array}$} & Aust. & 2.79 \\
\hline & Field & 3.54 \\
\hline \multirow{2}{*}{$\begin{array}{l}\text { Criticisms received by Oxfam Australia head office result in substantive } \\
\text { changes to OAus goals and strategies. }\end{array}$} & Aust. & 2.79 \\
\hline & Field & 3.54 \\
\hline \multirow{2}{*}{$\begin{array}{l}\text { Criticisms received by Oxfam Australia head office result in substantive } \\
\text { changes to country goals and strategies. }\end{array}$} & Aust. & 3.18 \\
\hline & Field & 3.50 \\
\hline \multirow{2}{*}{$\begin{array}{l}\text { Criticisms received by Oxfam Australia field offices result in substantive } \\
\text { changes to country programs. }\end{array}$} & Aust. & 3.25 \\
\hline & Field & 3.65 \\
\hline
\end{tabular}




\begin{tabular}{|l|l|c|}
\hline Statement & & $\begin{array}{c}\text { Level of } \\
\text { Agreement }\end{array}$ \\
\hline $\begin{array}{l}\text { Oxfam Australia field offices explain to partner organisations the reasons } \\
\text { for their responses to proposals or criticisms. }\end{array}$ & Aust. & 3.65 \\
\cline { 2 - 3 } & Field & 4.17 \\
\hline
\end{tabular}

Significant at a 95\% confidence interval

These divergent assessments show field office staff to have a generally more favourable impression of Oxfam Australia's existing accountability practices than do home office staff. These differing assessments of existing accountability practice make it harder to reach agreement within Oxfam about what changes are required. In order to work through the implications of these patterns for international development NGOs' attempts to strengthen the responsiveness of their accountability processes to staff, partners and communities in the countries where they operate, it is important to try and explain why experiences of accountability arrangements differ in these somewhat counterintuitive ways between those based in home office and field office locations.

\section{Why do field and home office staff express such different views of accountability?}

In order to explore possible explanations for these contrasting perceptions of accountability between home and field office staff, qualitative data was gathered from four of Oxfam Australia's country programs: Cambodia, Solomon Islands, Sri Lanka and Zimbabwe. This detailed qualitative data enabled a highly context-specific understanding of the organisational and political environments within which field staff work. ${ }^{1}$ Focus groups and individual interviews were held with OAus staff, partners and 'beneficiary' communities in each of these countries between August and November 2010. Where possible, in each country program all key NGO and community-based organisation (CBO) partners were interviewed. Additionally, all reasonable efforts were made to meet with a representative sample of partner communities based on location and poverty levels (as defined by OAus itself, usually via participatory rural appraisal processes). Half of the community focus groups were divided on the basis of gender, and half on the basis of hierarchy, as determined by representation on OAus-supported village development committees (or equivalent). Finally, this country program-focused research complemented existing qualitative date sourced from workshops on 'social accountability for development effectiveness' held by ACFID with Australian NGOs (including OAus) in July 2010, as well as from OAus surveys of staff on their perceptions of working within the organisation.

\footnotetext{
${ }^{1}$ The case material is analyzed in an inductive, exploratory manner, rather than in the form of a formal cross-case comparison.
} 
On the basis of the qualitative data relating to the four country programs, we suggest three overlapping institutional explanations for the contrasting experiences of accountability reflected in the survey data: that differently situated staff perceive accountability practices differently because they place greater interpretive weight on those practices most relevant to their own organisational roles; that divergent views reflect substantively different normative beliefs about what accountability should look like, influenced especially by political context; and that differing assessments of accountability practices reflect a strategic misrepresentation of field country experiences as a rational response to power differentials. All four country case studies offered evidence that was at least partly consistent with these three overlapping explanations, though the exploratory nature of the study prevents us advancing a definitive conclusion as to the relative importance of each explanation.

\section{The role of 'cognitive frames' in shaping interpretations of accountability}

A first explanation for the systematic differences between expressed perceptions about Oxfam's accountability practices revealed by the survey is that the different organisational roles and positions held by home versus field office staff-especially the differences between program management and implementation-encourage the two groups to pay attention to different dimensions of accountability in forming their overall evaluation of accountability obligations. As a result, each places greater implicit weighting on those relationships and practices most salient to their own role. That is, their assessments may disproportionately reflect assessments of those dimensions of accountability systems with which they have most direct involvement or interaction in the day to day performance of their jobs. This explanation is ultimately grounded in certain assumptions about the way in which individual respondents' 'interpretive frames' are conditioned by their own personal experiences.

One feature of field staff roles that appeared to be shared across all four country programs was that they tended to involve developing strong working relationships with partners and senior members of beneficiary communities. This reflects not only the greater proportion of program-oriented staff located in the field office, but also the overall tendency for field staff across a range of roles to have a stronger programmatic orientation, given their greater proximity to and responsibility for program implementation. This is in contrast to the typical roles of head office staff, who play an important role in integrating country programs with OAus' overall strategic direction and values, but usually have only sporadic contact with partners and communities - the possible exception to this arising in work on advocacy campaigns. 
The lack of direct interaction with partners and communities engaged in by home office staff was reflected clearly in discussions at the ACFID July 2010 workshops (Braun 2010). Very few ANGOs, especially among the larger organisations, saw themselves as having direct interaction with communities without the involvement of intermediary partners of some kind.

In contrast, staff members in all country offices played a hands-on role in carrying out programming and operations and monitoring and evaluation processes at the grassroots level, irrespective of the project implementation strategies employed. In the Zimbabwe program, for example, local staff described their role as being to ensure that the resources being deployed by Oxfam reach communities and make a meaningful contribution to changing their lives. Field officers reported extensive personal experience of community level outcomes associated with program activities, and most staff expressed generally positive experiences of these relationships. Similarly, in the Sri Lankan program, field staff emphasised the importance of direct relationships with communities in the day to day conduct of their work. They cited the example of their gender mainstreaming work, which constitutes a key element of the Sri Lankan program, much development work in this country program being devolved to CBOs comprising of mainly women. Field staff placed strong emphasis on this aspect of their work, and linked it to their own personal experiences of gender empowerment.

Examples such as these illustrate our general observation that field staff perceive themselves as having a higher level of control over, connection with and personal satisfaction from accountability relationships with affected communities than do home office staff. The different organisational roles and responsibilities of home versus field office staff, as well as the strong personal relationships and shared identification established between field staff, partners and communities appear importantly to influence how accountability practices are experienced and assessed by field office staff. This dynamic seems particularly important in explaining the disparity between field and home office staff in relation to downwards accountability.

To the extent that field staff identify positively with these dimensions of the organisation's work, in addition to simply experiencing them more directly, field staff's more positive interpretation of Oxfam's accountability arrangements might reflect a rosier view of the organisation's behaviour as a whole-accountability arrangements simply forming one part of this broader view. There is at least some anecdotal evidence from field offices suggesting that staff felt socially and professionally validated working with Oxfam because of the participatory way the organisation 
conducts many of its development interventions, and because of the prestige of its 'brand'. Either way, these kinds of 'interpretive frames' seem to play an important role in explaining the consistently more positive evaluations of existing accountability arrangements expressed by field as opposed to home country staff.

\section{Differing normative visions of what accountability practices should look like}

The second explanation we offer for the systematically divergent survey responses of field versus home office staff suggests that these two categories of respondents are implicitly comparing existing accountability practices against contrasting visions of what desirable accountability arrangements should look like. There is evidence that field and home office staff have different ideas about what kinds of decision making are most in need of strengthened accountability mechanisms, and make different assessments of the costs, benefits and risks of institutional reforms that attempt to achieve such strengthening.

To take one point of divergence, field staff place relatively greater emphasis on strengthening accountability mechanisms that relate to local operational decisions, as opposed to what they perceive as being more remote decisions relating to organisational goals and strategies, or the design of advocacy strategies. There is an emphasis on engagement with, and responsiveness to, local partners and communities around project decision-making.

This operational-level focus remains despite, or possibly because of, a clearly expressed awareness of the local-level political realities associated with implementing effective accountability arrangements linking actors in home and field office locations. Field staff acknowledge that many of the partners and communities they work with, because of local-level hierarchies and decisionmaking 'cultures', may not have the same beliefs about desirable accountability arrangements as OAus field or home office staff. This is seen as a cause of tension, which is reinforced by their consciousness of the accountability practices of other donors operating in the same locations. Nevertheless, field staff do not regard local resistance as discrediting accepted principles of accountability. Even where problems with inappropriate use of funds by partners have led staff in several of the country programs to value 'upwards' accountability in the form of probity controls by OAus, many field staff continued to express a belief in encouraging 'downwards' accountability practices involving partners and communities who transgressed established financial protocols, at least until it became clear that those actors were unlikely to change their behaviour as a result of 
ongoing engagement. This question was sometimes alternatively framed as one of synchronising head office ideals of accountability with local-level social and political realities.

This connects with a second major area of apparent divergence between views of field and home office staff that emerges from our four country program studies: the greater emphasis placed by field as opposed to home staff on the risks or costs of challenging existing power structures—both within the INGO itself, and within the wider social and political environment in the field country.

In all four programs significant concerns were expressed regarding risks and costs of excessively rapid changes to established power relations, especially at national and provincial levels of government. There was a widespread recognition among field staff that the political realities of working in countries such as Cambodia, the Solomon Islands, Sri Lanka and Zimbabwe, which have governments that exhibit varying levels of dysfunctionality, coercive practice and reliance on patron-client networks, meant that there were necessarily limitations to what OAus could achieve in-country, especially in relation to advocacy. In this context, the level of OAus accountability to partners and communities was generally evaluated positively, despite the fact that the local empowerment which improved INGO accountability to field country actors is intended to embody and foster was only sporadically in evidence. By way of contrast, some head office staff expressed higher levels of impatience and lower levels of caution in their appetite for more rapid and radical change. $^{2}$

To the extent that political constraints or disincentives to support rapid or radical change are present in a given context, field staff may hold substantively different visions of what accountability arrangements it would be reasonable or appropriate to expect, given their assessments of prevailing conditions and constraints. Implicitly then, they may be evaluating existing accountability arrangements not relative to some abstract 'ideal', but rather in relation to a more modest vision of a model that would be socially and politically feasible (at reasonable cost/risk) in the short to medium term. Such calibration of their evaluations could lead to precisely the kind of consistently more positive assessments that we observed in the survey findings.

To take one example, all international NGOs working in Cambodia have to be formally accredited by the government and submit yearly audit reports. The perception of OAus staff was that, while not particularly onerous, this accreditation process, along with the government's reputation for responding adversely to challenges to its power, enabled the government to exert restrictions on

\footnotetext{
${ }^{2}$ Sourced from the WILAH survey and personal communication of researchers with head office program staff
} 
NGO behaviour, especially in respect of advocacy campaigns. The field office in Cambodia has only discretely integrated advocacy activities in the projects it supports, often preferring to support other, local NGOs in their efforts.

Oxfam's activities in both Sri Lanka and Zimbabwe take place under possibly even greater constraints from the local political environment, although certain activities are more contentious than others. In Zimbabwe, the focus of Oxfam's programs on the issues of gender, HIV/AIDS and livelihoods support means that political interference is less intrusive than might be the case if they were operating around more overtly politicised issues. Similarly, in Sri Lanka gender empowerment and poverty reduction have been supported by government, and the response to the 2004 Indian Ocean earthquake and tsunami, focused on food security and crisis management, also appealed to basic survival needs rather than highly political issues.

Ethnic conflict in Sri Lanka was the most politically sensitive issue Oxfam was working on in that country; this sensitivity meant that NGOs operating in politically contested areas were subject to more government scrutiny, under a legislative framework requiring registration of and reporting by NGOs. The Zimbabwean government also used a number of control mechanisms to monitor and limit the operations of NGOs, particularly in the form of stringent and highly politicised registration requirements. Although the presence of severe political constraints are clearly recognised by home as well as field office staff, Zimbabwean field staff appear to see this as a rather separate issue to their accountability relationships with Oxfam, meaning that their assessments of the quality of these relationships are perhaps coloured less negatively by the existence of these constraints than is the case for home office staff. In contrast, Sri Lankan field staff recognised the importance of the home office in moderating such constraints, with the home office having directly intervened to protect CBO partners from militants, security forces and undue government interference.

On the surface, the Solomon Islands might appear to be the outlier on this issue of political constraint, the difficulties in managing partner and community relationships in an environment where patron-client politics is dominant creates its own set of restrictions paralleling those in other programs. Further, the Solomons exemplifies a situation existing in all the other cases, namely, that field staff work in a context where there is usually only a partial state presence. This creates a range of accountability problems, in the sense that OAus has only a limited capacity to respond to deeprooted power imbalances when the sites of political power are physically and politically so distant from large numbers of communities. 
Across all four country case studies, field staff were conscious of these kinds of political constraints, and this awareness appeared to condition their expectations about what kinds of accountability practices would be desirable or feasible under prevailing conditions. In contrast, home office staff often seemed to take less account of such political constraints when formulating normative visions of how they imagined accountability arrangements ought to work. As a result, home country staff seemed not to interpret field office and partner resistance to accountability strategies entailing pressures for deeper political change as expressions of different normative visions of feasible accountability practices. Rather, such forms of resistance were interpreted as reflecting a lack of field level capacity, or lack of information or understanding about the potential benefits of strengthened accountability. For example, such reservations were widely expressed by ACFID members in relation to their partners in the Pacific region, particularly in relation to accountability mechanisms associated with programs tackling women's position in society (Braun 2010). Such divergent expectations of home and field office staff were particularly notable in relation to assessments of downwards accountability, given the heightened sensitivity of field staff to the constraining influence of local political context on accountability of this kind.

Evidence from the case studies suggests that even among senior field office staff possessing comprehensive understanding of the implications of accountability changes, there remained a significant degree of caution about the risks and costs potentially entailed by more politically confrontational strategies of accountability. This suggests that these differences in views between home and field office staff cannot be explained simply with reference to different access to information, but rather should be understood as reflecting substantively different normative visions of what accountability arrangements can reasonably be expected to achieve in the presence of local political constraints. The prevalence of such contrasting expectations about what community centred accountability arrangements 'ought to' look like has the capacity to generate the systematic differences between survey responses of home and field office staff that we reported above.

Moreover, these differences in expectations of home versus field staff appeared in many cases to be reinforced by field staff's more extensive experience of the accountability practices of other donors operating in the same locations. In several countries, field staff reported a perception that OAus was more flexible and responsive to local needs within difficult political circumstances than many other international donors (though Sri Lankan staff seemed less inclined than interviewees in other locations to express this view). In this sense, the direct exposure of field staff to the practices of other donors appears to have influenced their relatively positive rating of OAus's accountability 
practices. In contrast, home office staff may be comparing Oxfam's performance against a more idealised yardstick.

\section{Strategic (mis) communication as a rational response to power differentials}

A third possible explanation of the divergent survey findings is that respondents from both field and home offices answered the survey questions strategically, meaning that the contrasting survey responses may not have accurately reflected the true perceptions or beliefs of field and/or home office staff. For example, the generally more critical evaluations expressed by home office staff may have reflected a desire to signal self-awareness of their own power and position within transnational relationships, thereby communicating commitment to principles of strengthened accountability. Such an attitude would accord with the findings of internal surveys conducted among Oxfam Australia staff, indicating that such staff perceive Oxfam to be committed to forms of accountability that contribute to redressing power asymmetries between itself, partners and 'beneficiary' communities, but also perceive the organisation as falling short in meeting those challenges. $^{3}$

Field staff, for their part, signalled in interviews and focus groups some level of caution in expressing criticism of an organisation wielding important forms of power over them, despite the researchers' assurances of independence and anonymity. Across the four country programs studied, consciousness among field staff of the power asymmetries between field and home offices was consistently high, though the specific issues around which these asymmetries were experienced varied across the programs, as did perceptions of the degree to which those asymmetries impacted on field office work. Such power dynamics help explain why field office staff reported more positive assessments of upwards as well as downwards accountability.

Field staff in the four countries noted power asymmetries between country and home offices primarily in relation to OAus processes of funding approval and financial accountability. Staff were cognisant that the head office held final approval of program and project funding, and that country programs had, in part, to make their case for funding in terms that correlated with head office's conceptual frameworks.

This lack of parity in organisational power was exemplified in the conduct of Oxfam International's (OI) shift to a Single Management Structure (SMS), which aims to reduce the number of Oxfam

\footnotetext{
${ }^{3}$ Most notably in the 'What's It Like Around Here' (WILAH) OAus internal survey
} 
affiliates 'on the ground' to one 'managing affiliate' in countries where Oxfam has a presence. In both Cambodia and the Solomons, OAus will not be the managing affiliate and is therefore beginning to devise exit strategies. SMS decisions were made by OI with only limited input from field staff, leaving staff with the perception that negotiations with OI are conducted by high level managers in the OAus head office, with little input from field offices.

Underscoring the general difficulties of securing undistorted feedback in surveys in the presence of significant power asymmetries, those researchers conducting our Zimbabwe case study noted widespread hesitation among OAus's local partners in offering frank responses to some of the researchers' questions. In some cases, partners had warned each other about the work of the researchers, and had seemingly prepared choreographed responses to structured questions in advance. Deeper probing revealed more critical views of existing accountability arrangements with OAus.

Consciousness of the strategic value of adapting communication to accord with head office assumptions was visible in a different form in the Sri Lanka program, where partner CBOs expressed concerns about the failure of OAus to log their verbal complaints, even though a number of $\mathrm{CBO}$ members were illiterate. Compounding the problem was the fact that responses to complaints were in writing and only made available in one of the two major languages. Field office staff were aware of the difficulties these practices raised for partners, but viewed these practices as necessary for meeting the probity demands of the head office.

\section{Conclusion}

For development NGOs seeking to manage and strengthen both their 'upward' and 'downward' accountability relationships, the question of how to interpret and respond to feedback from staff and stakeholders across the organisation poses an important practical challenge. This challenge is intensified when NGOs find themselves attempting to respond to 'mixed messages' received from different groups of staff and stakeholders. In such cases, it is important to try and understand why perceptions systematically vary across different levels of the organisation, since this helps lay the basis for a coherent organisational response to feedback. In response to this challenge, this paper has presented both empirical evidence and some initial explanatory propositions designed to help international development NGOs map and interpret feedback from staff and stakeholders regarding the strengths and weaknesses of existing accountability practices. 
Survey results found that field staff consistently expressed more favourable perceptions of existing accountability practices than home country staff. We put forward three overlapping explanations for these findings, each broadly inspired by elements of new institutional theory. The first explanation suggests that the different organisational roles and positions held by home versus field office staff encourage the two groups to pay attention to different dimensions of accountability in forming an overall evaluation of accountability practices, with each placing greater implicit weighting on those practices that are most salient to their own role. Second, we suggested that assessments of existing accountability practices may vary between home and field office staff because these practices are being implicitly compared against contrasting visions of what desirable or feasible accountability arrangements look like. The third explanation emphasises the role of unequal power relations between field staff and home staff: these seem to give field staff a greater incentive to answer the survey questions strategically based on a 'rational' interpretation of what they believe head office wants to hear.

Identifying these underlying reasons for divergent views of accountability has practical significance for organisational strategies of accountability reform, since desirable strategies are likely to vary depending on which explanation is doing the most work. The first explanation attributes different views of accountability to different interpretations of the problem. Because differences of interpretation on this view are largely grounded in the contrasting experiences of differently positioned staff, it follows that it would probably be useful to pursue a simple remedy of supporting better communication and deliberation between home and field office staff in building agreement about what kinds of accountability reforms are required, to enable varying experiences to be better understood.

The second explanation, emphasising substantively different visions of what desirable accountability arrangements look like, likewise suggests the importance of effective communication between staff in home and field office staff. However, the emphasis this explanation places on substantive disagreement about the costs, benefits and risks of different accountability reform strategies also highlights the importance of bringing more overt dynamics of bargaining and negotiation into such discussions, rather than relying mainly on consensual communicative modes. Substantive differences between the values and priorities of home and field staff can become obstacles to negotiating organisational change when they are not recognised, and instead become obscured by the fact of power asymmetries between differently positioned actors. While contrasting priorities of differently positioned actors within an INGO are difficult to overcome, they can be better understood, and entrenched differences negotiated more transparently. 
The final explanation, which suggests that field country experiences might be strategically miscommunicated as a rational response to unequal power relations between field staff and home staff, is perhaps the hardest dynamic to respond to in practice. It highlights the potential weaknesses of the more straightforward communicative strategies outlined above, in the presence of significant power differentials between participants. How such power differentials might be mitigated by organisational reform depends in part on the source of such power. Structural power disparities between home and field country actors, such as those associated with resource dependency, are difficult to escape. In contrast, those that are at least partly a product of an INGO's own organisational governance system could be more readily countered. For example, there might be a greater willingness among field country actors to communicate experiences and preferences bluntly if INGO decision making at higher strategic levels enabled greater field country representation and voice. Moreover, a greater role in processes of intra-organisational deliberation and negotiation for field country actors external to the INGO, such as partners and community representatives, could help strengthen the voice of field office experiences within power-laden processes of communication and bargaining.

Evidence presented from both surveys of field and home office staff and interviews with staff, partners and 'beneficiary' communities, indicated that the three explanations interact to drive the divergent feedback coming from home and field office staff. The first two explanations seem to carry particular weight in assessments of 'downwards' accountability practices, while the third explanation seems to influence assessments of both upwards and downwards forms of accountability.

Further research is required to subject these competing explanatory hypotheses to further empirical scrutiny, to separate out the relative weight of these overlapping causal dynamics, and to understand in more detail how they interact. Understanding these dynamics is important to our theoretical understanding of the facilitating and constraining conditions confronting agendas of INGO accountability reform. Building a better understanding of these dynamics can also inform our practical understanding of what organisational reforms within international development NGOs can best support the progressive strengthening of INGO accountability systems - an important goal to which the international development community is increasingly committed.

\section{REFERENCES}


Anheier, Helmut and Nuno Themudo (2002) 'Organisational Forms of Global Civil Society: Implications of Going Global', in Marlies Glasius, Mary Kaldor and Helmut Anheier (eds.) Civil Society Yearbook, Oxford, Oxford University Press.

Braun, Ann (2010) 'Australian NGO Accountability for Development Effectiveness', unpublished report, Canberra: Australian Council for International Development.

Campbell, Bernadette and Melvin M. Mark (2006) 'Toward More Effective Stakeholder Dialogue: Applying Theories of Negotiation to Policy and Program Evaluation', Journal of Applied Social Psychology 36(12):2834-2863.

Campbell, John L. (2005) 'Where Do We Stand? Common Mechanisms in Organizations and Social Movements Research, in Gerald F. Davis, Doug McAdam, W. Richard Scott and Mayer N. Zald (eds.) Social Movements and Organization Theory, New York: Cambridge University Press.

Craig, Gary and Marjorie Mayo (1995) Community empowerment : a reader in participation and development, London: Zed Books.

Dutton, Jane E. and Robert B. Duncan (1987) 'The creation of the momentum for change through strategic issue diagnosis’, Strategic Management Journal 8(3):279-295.

Gioia, Dennis A. and Kumar Chittipeddi (1991) 'Sensemaking and sensegiving in strategic change initiation', Strategic Management Journal 12(6):433-448.

Greenwood, Royston (1996) 'Understanding radical organisational change: bringing together the old and the new institutionalism’, Academy of Management Review 21(4):1022-1054.

Hall, Peter A. and Rosemary C. R. Taylor (1996) 'Political Science and the Three New Institutionalisms’, Political Studies XLIV:936-957.

North, Douglass Cecil (1995) 'Five Propositions about Institutional Change’, in Jack Knight and Itai Sened (eds.) Explaining social institutions, Ann Arbor: University of Michigan Press.

Pierson, Paul (2000) 'The Limits of Design: Explaining Institutional Origins and Change’, Governance: An International Journal of Policy and Administration 13(4):475-499.

Powell, Walter W. and Paul J. DiMaggio. (1991) The New Institutionalism in Organizational Analysis, Chicago: University of Chicago Press.

Reddell, Tim (2004) 'Third Way Social Governance: Where is the State?' Australian Journal of Social Issues 39(2):129-142.

Roche, Chris (2010) Promoting Voice and Choice: Exploring Innovations in Australian NGO Accountability for Development Effectiveness, unpublished report, Canberra: Australian Council for International Development. 
Scott, W. Richard and John W. Meyer. (1991). 'The Organization of Societal Sectors: Propositions and Early Evidence' in Walter W. Powell and Paul J. DiMaggio (eds.), The New Institutionalism in Organizational Analysis, Chicago: University of Chicago Press.

van Dam, Karen, Shaul Oreg and Birgit Schyns (2008) 'Daily Work Contexts and Resistance to Organisational Change: The Role of Leader-Member Exchange, Development Climate, and Change Process Characteristics’, Applied Psychology: An International Review 57(2):313-334. Walker, David W. (2009) 'Citizen-driven reform of local-level basic services: Community-Based Performance Monitoring', Development in Practice 19(8):1035-1051.

Westergaard, Kirsten (1994) 'People's Empowerment in Bangladesh - NGO Strategies', Centre for Development Research Working Paper 94.10. 


\section{University Library}

\section{- M M N E R VA A gateway to Melbourne's research publications}

Minerva Access is the Institutional Repository of The University of Melbourne

Author/s:

Davis, TWD;Macdonald, K;Brenton, S

Title:

Reforming accountability in international NGOs: making sense of conflicting feedback

Date:

2012-01-01

Citation:

Davis, T. W. D., Macdonald, K. \& Brenton, S. (2012). Reforming accountability in international NGOs: making sense of conflicting feedback. DEVELOPMENT IN PRACTICE, 22 (7), pp.946-961. https://doi.org/10.1080/09614524.2012.696093.

Persistent Link:

http://hdl.handle.net/11343/119553 